\title{
Stephen Bantu Biko: An agent of change in South Africa's socio-politico-religious landscape
}

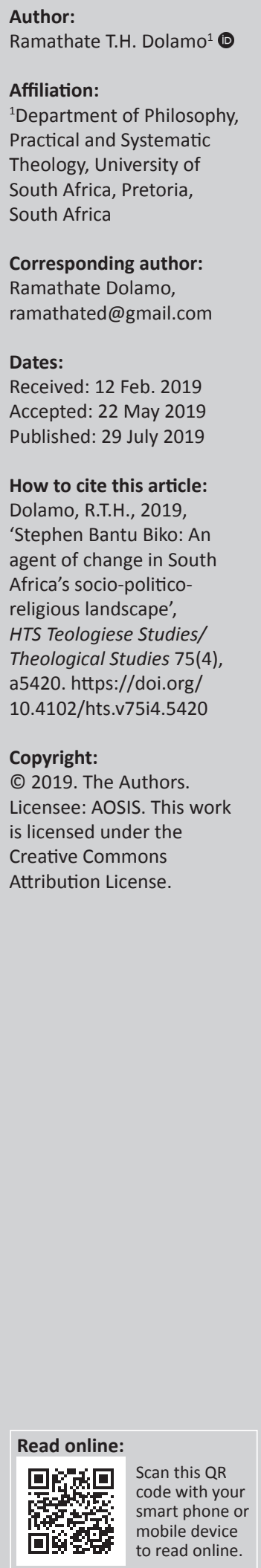

Author:

Affiliation:

1Department of Philosophy,

South Africa, Pretoria,

Ramathate Dolamo,

Dates:

Received: 12

Accepted: 22 May 2019

How to cite this article:

Dolamo, R.T.H., 2019,

Africa's socio-politico-

religious landscape'

a5420. https://doi.org/

Copyright:

(C) 2019. The Authors.

is licensed under the

Creative Commons

Attribution License.

\begin{abstract}
This article examines and analyses Biko's contribution to the liberation struggle in South Africa from the perspective of politics and religion. Through his leading participation in Black Consciousness Movement and Black Theology Project, Biko has not only influenced the direction of the liberation agenda, but he has also left a legacy that if the liberated and democratic South Africa were to follow, this country would be a much better place for all to live in. In fact, the continent as a whole through its endeavours in the African Union underpinned by the African Renaissance philosophy would go a long way in forging unity among the continent's nation states. Biko's legacy covers among other things identity, human dignity, education, research, health and job creation. This article will have far reaching implications for the relations between the democratic state and the church in South Africa, more so that there has been such a lack of the church's prophecy for the past 25 years.
\end{abstract}

Keywords: Liberation; Black consciousness; Black theology; Self-reliance; Identity; Culture; Religion; Human dignity.

\section{Orientation}

Biko was born in Ginsberg near King William's Town on 18 December 1946. He died in police custody because of wounds and bruises inflicted upon him on 12 September 1977. He was the 21st person to die in the hands of the police as the political detainee since the founding of Black Conscious Movement (BCM) (Stubbs 1978a:1-2; Wilson 1991:15). His father, Mzingaye, passed away when he was still 4 years old and his mother, Duna Mamcete who was a domestic worker, had to raise Bantu and his siblings all by herself. The family was God-fearing and denominationwise they were Anglicans (Wilson 1991:16-18).

When Bantu was about 16 years of age, he got arrested for activities related to the Pan Africanist Congress (PAC). Although he was later released from detention, he was nonetheless expelled from his school. This experience seems to have sown seeds of rebellion against authorities and people in power in general. He was admitted at a Roman Catholic School called St Francis College in Mariannhill in KwaZulu-Natal as a student in 1964. Biko was an inquisitive young man with a sharp intellect. Priests and nuns who ran the institution were asked very difficult questions, most of which were difficult for them to address and some very embarrassing for them because they had to do with their sexuality. He asked questions around the nature of the Church, its doctrines, traditions, and so on. For example, why should the church services be conducted in Latin when majority of congregants spoke isiZulu and did not know Latin? As Biko did not get satisfactory answers from those conservative monks and nuns, or as Biko himself says, their answers were either 'unintelligible' or 'unacceptable' (1978a:155), he befriended two clergymen who were more liberal in terms of theology and politics, namely Aelred Stubbs and David Russel. Other incidents that politically impacted on Biko were the 1960 Sharpeville massacre, the formation of the African National Congress (ANC) and PAC military wings, respectively, the apprehension of Nelson Mandela by the police and the Rivonia Treason Trial. Because of political persecutions and brutalities, many political leaders were either in prison or in exile. Fear was palpable across the country.

After matriculating at St Francis College, Biko went to the University of Natal in Wentworth in 1966 to study medicine. But while he was there, medicine was not his only preoccupation; politics became also central to his activities. He became a member of the National Union of South African Students (NUSAS). A defining moment politically dawned upon him when he attended NUSAS

Note: The Church in need of Change (agency), sub-edited by Erna Oliver (University of South Africa). 
conference held at Rhodes University in 1967. According to Wilson (1991) quoting Donald Woods, Biko said:

I realized that for a long time I had been holding onto the whole dogma of non-racialism almost like a religion, feeling that it was sacrilegious to question it, and therefore not accommodating the attacks I was getting from other students. I began to feel that there was a lot in the proponents of the non-racial idea, that much as they were adhering to this impressive idea they were in fact subject to their own experience back home. They had this problem, you know, of superiority, and they tended to take us for granted and wanted us to accept things that were second-class. (p. 23)

The use of the English language disadvantaged black students in that they were unable to follow discussions and make meaningful contributions and the white students exploited this deficiency. Black students accepted almost everything without question. Black students felt inadequate and not smart enough to engage their fellow white students. At that conference, Biko felt that a different kind of mental attitude must be created to counteract the white superiority or black inferiority mentality prevalent at the time. This led to an articulation of a philosophy known as black consciousness (BC) which led, in turn, to an all-black student organization called 'South African Students Organisation' (SASO). Black people would encompass so-called Bantus, so-called mixed race and Indians or Asians:

This new definition had a liberating effect on many, freeing them from the categories defined by apartheid, while others were extremely dubious of something that sounded as though it smacked of racism. (Wilson 1991:24-25)

Although it was initially agreed that SASO would not disaffiliate from NUSAS, the relationship became so polarised that SASO had to withdraw its membership of NUSAS.

\section{The term:}

'Non-White' was only used briefly and 'black' was adopted by the Black Consciousness Movement because, 'Non-White' was a negation of being. It still indicated a desire to become white eventually in the sense that 'whiteness' was the norm to which one attached other people who could not be defined in their own terms. (Wilson 1991:26)

SASO leadership divided portfolios among themselves. Some were given roles in education, development, performing arts and 'in political and theological matters Biko and Pityana led the field' (Wilson 1991:28-29). By the way, Biko was not only an Anglican by infant baptism and upbringing, but he also became a member of the University Christian Movement (UCM). He was also ecumenical in a way because he attended a Roman Catholic Church high school and at the university, he associated with students from other denominations (Duncan 2008:131). Although Biko was not a Christian in the traditional way of attending church services regularly and paying church dues, he nonetheless believed firmly in the existence of God when he said:

I have never had problems with this question. I am sufficiently convinced of the inadequacy of man and the rest of creation to believe that a greater force than mortals is responsible for creation, maintenance and continuation of life. I am also sufficiently religious to believe that man's internal insecurity can only be alleviated by an almost enigmatic and supernatural force to which we ascribe all power, all wisdom and love. (Wilson 1991:43)

Biko and his friends such as Nyameko Pityana, Mamphela Ramphele and Sabelo Ntwasa decided to visit theological seminaries in order to conscientise theology students. They were regarded as a strategic source because they were going to serve grassroots people in their pews and communities and that black people are very religious, it was an added advantage. A theology that would address black people in their context had to be manufactured at theological seminaries. This theology became known as 'black theology' (BT) (Duncan 2008:115-140; Motlhabi 2008:3-7; Stubbs 1978a:158). BC and BT were therefore propagated almost at the same time. They should be regarded as sides of the same coin. Biko truly believed that theology students graduating from such seminaries would confront apartheid and become honest interlocutors from a BC and BT perspective. For example, in 1968, he challenged UCM delegates at Fort Hare, 'to adopt the entire university as their responsibility, that is, he challenged all staff to see the connection between student responsibility and social concerns' (Duncan 2008:132-133). Because of the fact that Pityana held positions of leadership in both UCM and Anglican Student Fellowship, BT flourished more at Fort Hare than in other universities. Many seminaries such as Federal Theological Seminary (Alice), St Bedes (Umtata), St Peters (Hammanskraal) and Lutheran Theological College (Mapumulo) did revise their respective curricula with emphasis put on practical theology, community outreach as well as church administration and congregational work. As Pityana puts it, 'Biko built his political system on spiritual foundation ... spiritual is ... concrete, holistic, bringing the fullness of humanity to bear on the material and objective world' (cf. Duncan 2008:119).

Biko died a martyr according to Stubbs because he fought apartheid with single-minded integrity (1978b:214). Du Toit (2008:209) likens Biko to Diedrick Bonhoffer, Biko's associate and friend in the BCM and BT project. They immersed themselves in the struggle and soldiered on amidst trials and tribulations until 1994 with the inauguration of democracy in South Africa. Now that Biko's life and some activities have been discussed, it is time to focus more on his ideas, thoughts and insights.

\section{Black consciousness and black theology}

What is BC according to Biko?

Black Consciousness is an attitude of mind and a way of life, the most positive call to emanate from the black world for a long time. Its essence is the realization by the black man of the need to rally with his brothers around the course of their oppression the blackness of their skin - and to operate as a group to rid themselves of the shackles that bind them to perpetual servitude. 
It is based on a self-examination which has ultimately led them to believe that by seeking to run away from themselves and emulate the white man, they are insulting the intelligence of whoever created them black. (Stubbs 1978a:92)

The backdrop against Biko's definition of BC is the arrival of white people in South Africa in 1652. It was the beginning of the woes of the black people in that slavery, colonialism and apartheid were introduced in the continent (Marsh 2013:207208). 'Colonialism and conquest brought about immense changes in the African societies of Southern Africa, impacting radically on their economies, cultures, thoughts and ways of life' (Odendaal 2012:9). Odendaal (2012:3) says that, 'indigenous people had been subjugated, enslaved, deprived of their land and freedom, even in places exterminated, all in the name of Western civilization and progress'. The Land Acts of 1913 and 1936 ensured that black people were stripped of 87\% of their land (Changuion \& Steenkamp 2012:130-139, 163-175) and racism was formally legislated for in 1948 in the form of apartheid when the National Party ascended to power (2012:86-200). Homelands were created with Transkei, Venda, Ciskei and Bophuthatswana being given 'independence' by the apartheid government (2012:214-232, 232-250). Indians and so-called mixed race were incorporated into the central parliament in an arrangement called Tricameral Parliament (2012:252-253).

The tense situation in South Africa became worse as the National Party became vicious in implementing its apartheid policy. The ANC and PAC were banned in 1960 after the Sharpeville massacre and they went underground and formed Umkhonto we Sizwe and Poqo, respectively. Thousands of students went into exile following the 1976 students uprising against apartheid, while others were imprisoned either on Robben Island or in the mainland. There was fear in the hearts of many people and the population became paralysed (cf. Brotz 1977; Davenport 1987; Lodge 1983; Motsoko 1984). This 'pathological fear' as Pityana (2008:5) called it had to be dealt with first on the psychological level before the physical shackles of oppression can be removed.

There were influences beyond South Africa that also helped Biko and others to formulate the BC philosophy, for BC is not really a new phenomenon on the global map. These advocates of BC were avid readers and they followed very attentively political developments in Africa and beyond. For example, Sono (1993:95) tells us that Biko read in 1 weekend the 460 pages of 'Autobiography of Malcom $X^{\prime}$. They read extensively on the American Black Power ideology, Kwame Ture (aka Stockley Carmichael, Charles Hamilton, Franz Fanon, Martin Luther King Jnr and Paul Freire including Elijah Muhammad. This period was also marked by many colonised countries in Africa getting their independence. South Africa would follow much later in 1994.

They received inspiration from those political leaders of liberated Africa such as Kwame Nkrumah, Julius Nyerere and Leopold Senghor by reading their works (Sono 1993:37).
Other influences include the Ethiopian Movement, ANC and PAC (Pityana in Du Toit 2008:7). For Khoapa (Du Toit 2008):

... the oppressed the meaning of the struggle against dehumanization is located in the great humanistic and historical task of liberating both themselves and their oppressors. The object of the struggle is to create an order that dehumanizes no one. (p. 75)

Biko (1978:73-79) discusses in depth the genesis of the fear that gripped the nation referred above.

Indigenous people were dealt with harshly when they held on to their land, livestock, and so on, and in some instances, they were killed. Colonialists used any means to hang on to power. People were charged under vicious laws enabled by the Terrorism Act. Biko (1978:75) went so far as to equate apartheid to Nazism.

Arrests and torture were effected on a daily basis and as he says:

No average black man can ever at any moment be absolutely sure that he is not breaking a law. There are so many laws governing the lives and behaviour of black people that sometimes one feels that police only need to page at random through their statute book to be able to get a law under which to charge a victim. (Biko 1978:75)

White people also lived in fear that black people would revolt against them and all the signs were there that black people would not submit to state-sponsored violence against them. They called it 'swart gevaar' or black danger. Having exorcised the demon of fear and having a programme of action in place, BC proponents decided to spread BC philosophy especially among students from high school to tertiary institutions and the SASO was born.

SASO was launched at the University of the North, now University of Limpopo, in July 1969 and Biko was elected as its first president. SASO would offer black students a forum from where to discuss problems unique to them. It was felt that NUSAS and UCM did not discuss material issues affecting them but only those pertinent to white survival (Biko 1978a:67; Seleoane 2008:33-34; Sono 1993:31). For Sono (63), SASO is the soul of liberation!

Briefly, the aims and objectives of SASO were as follows:

1. The needs and aspirations of black students need to be crystallised. For example, why did apartheid state decided to establish ethnic universities in 1959?

2. Programmes were designed through which those aspirations would be embarked upon. For example, students were encouraged to spend their vacations in communities to do community work.

3. Contacts and interactions had to be increased among black universities because it was the intention of the government of the day not only to separate black and white students but also to separate black students along ethnic groupings. 
4. Solid identity among all black universities had to be fostered around their blackness. They are a majority as black students and were therefore a formidable force to reckon with.

5. Black students were encouraged to act as pressure groups on their respective campuses. This call was made at the time when black campuses did not have credible Student Representative Councils.

6. Awareness on socio-political issues in South Africa had to be raised among all and sundry. Where do we come from as black students, where are we and where do we want to go? (Biko 1978d:3-7)

Corroborating this presentation Biko (1978d) said:

We have a responsibility not only to ourselves but also to the society from which we spring. No one else will ever take the challenge up until we, of our own accord, accept the inevitable fact that ultimately the leadership of the non-white peoples in this country rests with us. (p. 7)

Although SASO to many seemed to have been racially inclined:
... Yet what SASO has done is simply to take stock of the present scene in the country and to realise that not unless the non-white students decide to lift themselves from the doldrums will they ever hope to get out of them. (p. 5)

Biko denied vehemently when he was accused of being anti-white. SASO was not to be understood as conforming to the policy of separate development either. Actually, Biko demonstrated that SASO or any other exclusively black organization would not last (1978c:11-12).

Yet, we have to admit, according to Biko (1978c:12), that our society is not normal. White people will continue to dominate everything especially positions of leadership and will continue to perpetuate the status quo and preoccupy themselves with problems affecting white society. Black people are tired of being in the periphery of power and being left out of decision-making processes in South Africa. According to Biko (1978c):

... [T] he black student community has at last lost faith with their white counterparts and is now withdrawing from the open society ... They want to do things for themselves and all by themselves. (p. 15)

After the formation of SASO, the BC leadership discussed the fate of graduates who left institutions of higher learning to go and work and interact with society. These former students were mature and would be good ambassadors of the philosophy. To this end, a decision was taken to establish a political organisation and the Black People's Convention (BPC) was launched in December 1971 with Biko as its honorary president. By that time, the apartheid regime had realised that SASO was not conforming to the policy of separate development as they had initially thought, but was a revolutionary organisation that wanted to topple it. The government was already hitting hard on the leadership of
BCM. Pro-Frelimo rallies of 1974 and followed in 1976 by the student uprisings demonstrated to the regime that $\mathrm{BC}$ was a potent and strong force to reckon with. People such as Biko were either in detention or under house arrest. SASO and BPC were banned in October 1977 with thousands of students and BC leaders incarcerated or going into exile. Some newspapers which were aligned to $\mathrm{BC}$ were also banned.

Another wave of fear engulfed the country but the struggle was not abandoned. Organisations such as the Azanian People's Organisation (AZAPO), the National Union of Mineworkers (NUM) and the United Democratic Front (UDF) continued with the struggle until apartheid was vanquished in 1994. Lauding the role that BCM played, Buthelezi (in Pityana 1991) had this to say:

The $\mathrm{BCM}$ can be said to have prepared the way for the bolder moves of the 1970s and 1980s, which culminated in the events of the 1990s. The impact of BCM goes beyond particular organisations. The psychological liberation brought about by the BC Philosophy enabled blacks particularly the young to overcome their fear of the repressive system they were up against. (p. 129)

Regarding matters religious, Biko was of the firm belief that religion is fundamental to human beings and therefore should be made readily available to everyone. Religion will definitely be with us forever because where there is no religion, one will be developed (Stubbs 1978a:55, cf. Duncan in Du Toit 2008:127). Religion forms people's moral conscience and it offers solutions where science is unable to do so. For that reason, professional theologians should stop monopolising religion and regarding themselves as the only category of Christians who know all the truths about God and have all the answers. Turning to BT in particular, it has already been indicated that it was regarded as a spiritual counterpart of $\mathrm{BC}$ because the same people who formulated and articulated BC are the same as those who proposed and articulated BT. Theology is God's word to a particular situation and its motif is liberation. BC laid bare the oppressive and exploitative situation in which black people found themselves in South Africa and the question was, of course, where was God in the situation, if indeed we are all, black and white created in God's image and likeness. It was high time that God addressed them relevantly and BT was born. Biko (in Stubbs 1978a) defined BT as follows:

Black Theology ... is a situational interpretation of Christianity. It seeks to relate the present day black man to God within the given context of the black man's moral obligation from avoiding wronging false authorities by not losing his Reference Book, not to stealing food when hungry and not cheating police when he is caught, to being committed to eradicating all course for suffering as represented in the death of children from starvation, outbreaks of epidemics in poor areas, or the existence of thuggery and vandalism in townships. In other words, it shifts the emphasis from petty sins to major sins in a society, thereby ceasing to teach the people to 'suffer peacefully'. (p. 59)

The Bible indicates that God's message is addressed to people's histories and situations and should be adapted in 
line with the aspirations and hopes of the people if it is to be relevant. In other words, the gospel must be contextual if it has to be salvific and liberating. Black theology is therefore not a new theology but rather a re-evaluation of the same gospel message contained in the Bible. Biko takes issue with the so-called 'pie-in-the-sky' theology because it is ideological and it is open to abuse by those in power against the powerless and the poor. God's message of salvation is not only meant to prepare candidates for heaven, but it is also meant to liberate people from the physical shackles here and now. According to Biko (in Stubbs 1978a), BT:

\begin{abstract}
... seeks to relate God and Christ once more to the black man and his daily problems. It wants to describe Christ as a fighting God, not as a passive God who allows a lie to rest unchallenged. It grapples with existential problems and does not claim to be a theology of absolutes. It seeks to bring back God to the black man and to the truth and reality of his situation. (p. 94)
\end{abstract}

BT is black, not only in terms of skin pigmentation but also in terms of those who suffer in South Africa and everywhere else in the world, the majority of which happens to be black. Black theory also makes a clarion call to all the black people to become agents of their own liberation, if they ever hope to come out of the physical and mental ghettoes and doldrums in which they have been thrown by those in power. BT in South Africa was also influenced by theological developments in the US. A leading African American theologian, Cone (1978) almost at the same time as black people in South Africa were speaking of BT, was also canvassing black theologians and lobbying black churches to embrace a new methodology of doing theology from the black perspective. In as much as BT in South Africa relied on BC philosophy for doing theology, BT in the US depended on the analysis performed by the Black Power and the Black Panther Movements (Pityana in Motlhabi 1972:41, Motlhabi in Motlhabi 1972a:55, Duncan in Du Toit 2008:116, Cone in Motlhabi 1972a:28). Many South Africans went to study BT in Europe and the US from the 1960s to the 1990s. Collaborative conferences were also convened both nationally and internationally as black people globally were trying to understand their common plight and their position in the world.

Biko challenged theology students and pastors to embrace spiritually the aims and objectives of BC. Biko (in Stubbs 1978a:8-16) noted that black students in multiracial organisations were always voiceless (1978a:8-16). He was particularly worried that even in organisations where black students were in the majority of $70 \%$ and above, leadership positions were occupied by white students (Sono 1993:29). For example, the Church in South Africa is $90 \%$ black but its leadership is predominately in white hands (1978a:57). He laments the spiritual poverty in which black people find themselves and indicates that 'material want is bad enough but coupled with spiritual poverty it kills' (Biko in Stubbs 1978a:14). Black people have been prepared for a subordinate role in South Africa. They have been convinced that they are inferior and have inherent inabilities and were mentally retarded. This is the extent to which black people have been dehumanised (Biko in Stubbs 1978a:28).
Biko was concerned that Christianity continued to be preached in a way that does not address the context in which black people found themselves in the country but instead, the "ministers are still too busy with moral trivialities ... While they [blacks] sing in a chorus of "mea culpa" they are joined by white groups who sing a different version-"tua culpa"' (1978:30). For Biko, the Bible message has to be redefined if the Bible is to become a travelling companion and sustenance for the black people on their journey to democracy (1978:31).

Taking a swipe at the missionaries, Biko argues that they are no better than other white people in their paternalistic attitude. They have also made themselves perpetual guardians and tutors of their black converts and they never bothered to relate sin to structural injustices. Biko did acknowledge though the good work performed by the missionaries such as building schools, colleges and hospitals (1978f:56). Missionary education was so good that the Nationalist Party stopped it in 1953 when the Bantu Education Act was passed. The Church in general is guilty of condemning people for immoral acts without relating those moral lapses to socio-political conditions in which they find themselves. For example, how does one simply condemn adultery or fornication in the mines without relating that to the migratory labour system where men were allowed to visit their families only once a year for just 2 weeks? asked Biko (1978f.:57).

Biko, concluding his presentation he gave in May 1972 in Natal at a conference of black ministers of religion, put it bluntly to the religious leaders when he said, '... God is not in a habit of coming down from heaven to solve people's problems on earth' (1978f.:60). In other words, as humans we have been made cocreators with God and in that manner, we have to become agents of change in transforming this world. In the light of what BC and BT stood for and in particular the teachings and actions of Biko, are there some lessons that the democratic South Africa can learn? The next section looks at some of Biko's ideas and thoughts that could assist us in South Africa today. There are those who believe that BC and BT as well as Biko are no longer relevant but there are others who believe that there is a great deal that we could be offered by Biko as we nurture our nascent democracy.

\section{Biko's legacy and contribution}

While it should be admitted that Biko's challenges are not very similar to those we are facing today, we should at the same time admit that there are principles and values including his insights that could be leveraged today to assist us in nation building. The following are the few that we believe can only be ignored at our peril.

(1) Black and African identity: White people, that is, colonialists, traders and missionaries when invading the African continent and lands elsewhere, made sure that the conquered peoples were emptied of their identities. They called them all sorts of names such as savages, uncivilised 
and pagans. As Odendaal (2012:3) puts it, during the five centuries of global colonisation:

Indigenous people had been subjugated, enslaved, deprived of their land and freedom, even in places exterminated, all in the name of Western civilization and progress. This process of coercion, justified by ideologies of racism and often explained in religious terms, continued in institutional forms in colonial territories and became part of the fabric of life under colonization. (cf. Mzimela 1983:192)

The theory of evolution, eugenics and racism with the benefits of better communication, weaponry and advanced medical capabilities made colonialism easier according to Marsh (2013:239). The 19th century reinforced the ideas of the inferiority of the conquered and superiority of the conquerors. Science was used to justify racism and the Anglo-Saxons were put at the top of the ladder of civilisation and darker races were put closer to animals (Motlhabi 1972a:2; Murove 2009:20). Odendaal (2012) quotes 1863 Edinburgh Review:

There is no vast difference between the intelligence of a Bosjeman (Bushman) and that of an orang-utan, and the difference is far greater between Descartes or Homer and the Hottentot than between the stupid Hottentot and the ape. (p. 6)

Winston Churchill is quoted as having said that the Sudanese Mahdist 'trash' and referred to Indians as 'beastly people with a beastly religion' (Odendaal 2012:7). The strategy was therefore to wipe the slate clean and create a tabula rasa in the minds and hearts of the colonised on which to write a new culture and new religion. That is why for Biko, it was crucial for black people to be liberated first mentally and spiritually. The disparities in material conditions between black and white people led to different aspirations because black people want to attain what they have been denied all along and white people want to hang on to their life of privilege that they have enjoyed since 1652 . While black people have attained political emancipation and are ruling the country, about $80 \%$ of the economy of the country is still in white hands. The land issue is still a burning one: how should it be distributed? The 'rainbow-ism' mentality should not be used to sweep South Africa's problems of poverty, unemployment and inequality that affect mostly black people under the carpet. Legislation for and methodologies of nation building should be performed with a bias towards the black majority who have been pushed to the margins of the South African economy by apartheid.

(2) Biko's leadership style: He believed that decisions should be taken by leadership as a collective and:

His leadership qualities were such that he never reviled his foes and opponents, only their principles. He refused to descend to the level of vilifying his opponents or foes on a personal level. (Sono 1993:93)

He cultivated a culture of discursive thinking for he honestly believed in arriving at decisions that have been thoroughly debated. Pityana (in Du Toit 2008:4) indicates that many of the essays in I Write What I Like were so much a product of extensive and intensive discussions among them that a correct title should have been We Write What We Like. Effort was taken to avoid a leadership cult even when Biko was accepted as the visionary and luminary leader of BC and BT (Stubbs 1978b:158). Consensus politics defined management of the BC organisations:

There grew into being a particular style of leadership which recognized and enormous advantage of widespread consultation to win over a proposal but the creation of an atmosphere where individual opinions were considered and taken seriously. They were valued equally. (Sono 1993:27)

Although Biko was not willing to found a political party other than SASO, he yielded to the formation of BPC, the reason being that postgraduate students in the work place would find a home in which they would deal with black people's plight in society in general. This is a stark example of what collective leadership entails, that is, even if you are a leader, you accept a decision of the majority. When it was discussed as to which organisations to approach and to interact with, Biko (in Stubbs 1978a:80-86) argued strenuously against entering into dialogue with homeland leaders. Politically, Bantustans are a fraud. Bantustan leaders are confusing the masses as if something earth shattering was about to happen. "These tribal cocoons called "homelands" are nothing else but sophisticated concentration camps where black people are allowed to 'suffer peacefully' (1978a:86). In this instance, Biko won the argument and when Temba Sono as a president of SASO insisted on collaborating with homeland leaders, he was expelled from the organisation with immediate effect (Sono 1993:97).

Although Biko was against the use of violence to overthrow the apartheid state, he was keen to discuss the future of South Africa with other organisations such as the ANC, PAC and New Unity Movement (NEUM) even though he knew that pacifism might take years to achieve liberation (Sono 1993:106). BPC did not want to become a political party as already alluded, but simply an internal organisation that would keep the home fires burning until the exiled and imprisoned leadership had returned. The BPC when being launched in June 1972 put this statement across that it was not replacing other liberation movements. It was not even in competition with them. It was geared at becoming a unifying force to create a national consciousness. In fact, the leadership in exile and on Robben Island was recognised as true and authentic leadership. To raise this national consciousness, BPC under Black Communalism organised meetings between 1974 and 1975 (Ramphele in Pityana 1991:222; Wilson in Pityana 1991:55, 64). According to Sono (1993:101), Biko would have taken part at the Convention for a Democratic South Africa (CODESA) negotiation table had he lived, and this was the decision taken by Azanian People's Organisation (AZAPO) on CODESA. Biko 'strongly believed that South Africa's future could only be bargained for, negotiated for, by blacks who would have assumed a pivotal role in shaping the agenda on the table'. BCM (Azania) was strongly opposed to negotiations with the minority white regime and explicitly 
excluded white people from participation in creating Azania (new South Africa), while Biko believed that white people had a constructive role to play. BCM (A) called for the dictatorship of the black proletariat and insisted that power had to be transferred to the black majority without negotiations. For AZAPO, this position was nothing but a pipe dream. Negotiations were necessary as long as majority rule was the end game. AZAPO wanted the economy to be socialised as opposed to free market economy (Sono 1993:117).

Biko was a leader who wanted unity of the black people not only within the BCM family but also across all liberation movements. I believe that Biko should be turning in his grave when he sees splinter groups such as $\mathrm{AZAPO}, \mathrm{BCM}(\mathrm{A})$ and Socialist Party of Azania (SOPA) claiming to embody his ideals being at each other throats. Unifying all political parties for the purpose of freedom for all, black and white was necessary for according to Biko, 'In time we shall be in a position to bestow upon South Africa the greatest gift possible - a more humane face' Sono 1993:89).

In as much as Biko widely read politics, he also had time to read theology and he was not happy about matters pertaining to the practice of religion. He raised, for example, issues around the 'enculturation of the gospel' and the 'indigenisation of the Church'. The former refers to the gospel being stripped of the wrappings and trappings of the Western culture and taking on African culture and all its aspects and the latter refers to the leadership of the Church in Africa being reflective of the demographics of the continent. He believed that the institutionalisation and bureaucratisation of the Church was not only unnecessary but it was also complicating things for the ordinary congregants.

Church leadership spent too much time on administrative functions and financials that there was hardly any time left for the core business of the Church which is the preaching of the gospel of Jesus Christ whose central message is liberation (Stubbs 1978b:210). According to Biko, ministers do not address black aspirations, because they, 'are still too busy with moral trivialities' (Stubbs 1978a:31). Biko is here backed by the Scripture text that says:

It is not right for us to neglect the preaching of God's word in order to handle finances. So then, brothers, choose seven men among you .... and we will put them in charge of this matter. We ourselves, then, will give our full time to prayer and the work of preaching. (Ac 6:2-4)

He complained about the monopoly of theology by professional theologians and pastors. Through this practice, they became the repositories of God`s truth and interpreters of heavenly mysteries. It baffled him that Latin until fairly recently was used in the Roman Catholic Church services, particularly black priests '... could not understand how the dignity of the liturgy could be so heavily prostituted by the substitution of Latin with Zulu ... Somehow Latin seemed a holier medium' (Stubbs 1978:176). What for Biko was unforgivable was denominationalism (Duncan 2008:122; Stubbs 1978b209). Which of these denominations interpret Christianity correctly? They compete with one other and even fight among themselves about doctrines and trivialities that have nothing to do with liberation. Biko says that in his:

... view the truth is in my ability to incorporate my vertical relationship with God into the horizontal relationships with my fellow men; in my ability to pursue my ultimate purpose on earth which is to do good. (Stubbs 1978b:210)

His criticism of the state as not being ordained by God, so was the Church. For him, the Church was no different from other earthly institutions and social clubs. He therefore had a democratic right to withdraw from the Church if it did not meet his expectations any longer without fear of eternal condemnation. Biko was quoted to have said, 'I can reject all churches and still be Godly' (Stubbs 1978:210). All what he was interested in was the revolutionary message of the historical Jesus (Sono 1993:90). Roman Catholic Church's teachings on the infallibility of the Pope, ex cathedra statements, extra ecclesiam nulla salus pronouncements, put the Church above criticism and that could not be accepted. Even St Paul was not spared because he accused him of having contaminated the whole theology with his conservative teachings on church and state relations (Stubbs 1978b:211). For Duncan (in Du Toit 2008:122), Biko's attitude towards the Church helped him to obey God rather than humans. Biko did not believe in the divinity of Christ but in the historical Jesus of Nazareth. He therefore rejected the doctrine of the Virgin Birth including Christ Resurrection from the dead. Biko said if we were to follow this line of argument, 'It is either we are worshipping an illegitimate child as our God or we are elevating a normal human being into the status of God's son' (Stubbs 1978b:211). The revolutionary Jesus is the one that appeals to Biko.

(3) Education and research: For Biko, education and research were important instruments by which black people would rediscover their identity and restore their pride and dignity. Under his leadership, much was performed in terms of rewriting and reinterpreting African history, redefining African culture and appreciating African religion more (cf. Biko 1978:40-47, 54-60, 87-89; Buthelezi 1991:111-129; Seleoane 2008:15-56). Black consciousness was conceptualised and developed by students and a perception was created that BCM was for academics and intellectuals. Biko was so passionate about education that one does not believe that the slogan, 'liberation first and education later' originated with Biko. What one can submit without hesitation is that Biko's stance could have been that of education for liberation rather than liberation without education. Many advocates of BC and BT were well educated with qualifications from worldclass universities abroad. Many of the 1976 students who sought political refuge abroad took the option of pursuing studies rather than joining Umkhonto we Sizwe or Poqo. Here at home, some students subjected themselves to Bantu Education system, inferior though it was. Biko's expulsion from the University of Natal (Wentworth) did not discourage 
him from pursuing his studies; he registered with the University of South Africa for a law degree.

Biko initiated a culture of research. He complained that black people had become objects of research and the abiding mentality was that they were victims of racism deserving therefore of pity. Paternalism was the order of the day so much so that BC and BT advocates '... were determined to transform research and publication by and about black South Africans' (Ramphele in Pityana 1991:161). It was in 1972 when Biko launched Black Review and the aim was to counteract the negativity displayed out there by the South African Institute of Race Relations (SAIRR) as well as newspapers such as Post and World that black people were to be pitied. These publications projected black people as '... a people without any achievements, a community of failures who were noted for murder, rape, theft, and family disorganization' (Ramphele in Pityana 1991:162). BC and BT activists needed to embark on reflective and reflexive research '... which would take seriously the problems of the black community, their survival strategies, as well as their efforts to transform their life circumstances' (Pityana 1991:162). Welile Nhlapo and Tomeka Mafole worked closely with Biko as his research assistants when he worked on Black Review. Two more publications were launched by Biko, called Black Viewpoint in 1972 and Black Perspectives in 1973 respectively. BT and BC collaborated on other research projects such as Special Project for Christian Action in Society (SPROCAS) and Pro Veritate. Father Smangaliso Mkhatshwa headed a BT research project called the Black Renaissance Convention (BRC) which held its conference in Maseru, Lesotho, in 1975 (Motlhabi 2008:168-170). A journal called, Black Theology in South Africa, was launched and BT as such was integrated into a theological organisation called, Institute for Contextual Theology. This move broadened considerably the scope of BT because issues then included gender justice, class, landlessness and environmental justice. Two important publications followed, namely The Unquestionable Right to be Free published in 1986 and Hammering Swords into Ploughshares also published in 1986, both edited by Itumeleng Mosala and Buti Tlhagale. More conferences were held under the auspices of an organisation called, Community of Black and African Theologians (COMBAT).

(4) Development projects: It became clear to Biko that liberation would not be achieved overnight and therefore self-help projects would be necessary. But not only that. Biko wanted to inculcate culture of self-reliance because begging makes people to lose their dignity and humanity. (Biko 1978a:38). As Ramphele (1991) says:

The dual onslaught of political impotence, induced by state repression, and economic dependency, resulting from poverty and welfarism, wrought havoc on the self-image of black South Africans, who lost self-confidence as a people. (p. 156)

As a result of this realisation, Biko and SASO decided to embark on community projects that would restore black pride. Literacy advocacy, adult education, employment opportunities, skills training, health promotion, and so on, were sponsored by Black Community Projects (Ramphele 1991:154-178; Sono 1993:70). Ramphele regards these community projects as 'tools of empowerment and symbols of hope' (1991:154). As Buthelezi (in Motlhabi 1972a) puts it:

Our ultimate ethical responsibility is not only to serve man by removing the symptoms of alienation from the wholeness of life, but to equip them with the tools which will enable them to stand on their own feet. (p. 129)

Quite a number of projects were started across the country. The New Farm Settlement Project was founded in 1969-1971 in Durban. The Dududu Project was established at the Natal South Coast; The Winterveld Project in Pretoria; The Zanempilo Community Health Centre, Solempilo, founded near Adam's Mission; and The Zimele Trust Fund and Ithuseng Clinic in Lenyenye near Tzaneen.

It is a pity that only very few of those projects survived the political storms. It was difficult to source funds under apartheid for politically motivated projects. In fact, with the adoption of the Affected Organisations Bill of 1974, all $\mathrm{BC}$ organisations and affiliated ones could not receive funding from abroad. Even under democracy, it is difficult to raise funds because many sponsors directed their donations to the government and as a result, many nongovernmental organisations were closed. The philosophy of Biko on self-reliance came in handy. Jesus has warned us that the poor will be with us always (Jn 12:8), thus preparing us for a lifelong battle against poverty, unemployment and inequality.

\section{Concluding remarks}

If we adhere to some of Biko's core values and basic principles, we can take South Africa to a higher level. Firstly, we need as South Africans to move from the apartheid mentality of regarding ourselves as white versus black and become one nation comprising black and white people. Secondly, we need to reposition ourselves through the renaissance philosophy as Africans in Africa. Thirdly, education and research need to be prioritised together with health and economic growth through supporting small business. Moreover, for all of these deliverables to happen, corruption must be ruthlessly dealt with. Even during apartheid Biko discouraged violence and he would be appalled by state violence and mob violence in a democratic South Africa. Of course, there are issues that are bedevilling us today that Biko and his contemporaries did not address then but which we should firmly put at the top of our agenda as well such as gender justice, land and environmental justice. Such issues could still be addressed through using Biko's core values and principles as well as those found in the Bible. Women need to be liberated from patriarchy, restoration of land to its owners would restore African dignity and mismanagement of God's creation would hit the poor the hardest. 


\section{Acknowledgement}

\section{Competing interest}

The author declares that no competing interest exists.

\section{Author contributions}

I declare that I am the sole author of this research article.

\section{Funding}

This research received no specific grant from any funding agency in the public, commercial, or not-for-profit sectors.

\section{Data availability statement}

Data sharing is not applicable to this article as no new data were created or analysed in this study.

\section{Disclaimer}

The views and opinions expressed in this article are those of the authors and do not necessarily reflect the official policy or position of any affiliated agency of the authors.

\section{Ethical consideration}

This article followed all ethical standards for carrying out research without direct contact with human or animal subjects.

\section{References}

Biko, S.B., 1978a, 'Fear: An important determinant in South Africa', in A. Stubbs (ed.) I write what I like, pp. 73-79, The Bowerdean Press, London.

Biko, S.B., 1978b, 'Let's talk about bantustans', in A. Stubbs (ed.), I write what I like, pp. 80-86, The Bowerdean Press, London.

Biko, S.B., 1978c, 'Letter to SRC presidents', in A. Stubbs (ed.), I write what I like, pp. 8-16, The Bowerdean Press, London.

Biko, S.B., 1978d, 'SASO - Its role, significance and its future', in A. Stubbs (ed.), I write what I like, pp. 3-7, The Bowerdean Press, London.

Biko, S.B., 1978e, 'Some African cultural aspects', in A. Stubbs (ed.), I write what I like, pp. 40-47, The Bowerdean Press, London.

Biko, S.B., 1978f, 'The as seen by a young layman', in A. Stubbs (ed.), I write what I like, pp. 54-60, The Bowerdean Press, London.

Biko, S.B., 1978g, 'White racism and black consciousness', in A. Stubbs (ed.), I write what I like, pp. 61-72, The Bowerdean Press, London.

Biko, S.B., 1978h, 'Black consciousness and the quest for true humanity', in A. Stubbs (ed.), I write what I like, pp. 87-98, The Bowerdean Press, London.
Biko, S.B., 1978i, 'We blacks', in A. Stubbs (ed.), I write what I like, pp. 27-30, The Bowerdean Press, London.

Brotz, H., 1977, The politics of South Africa, Oxford University Press, London.

Buthelezi, M., 1972, 'The theological meaning of true humanity', in M. Motlhabi (ed.), Essays on black theology, pp. 71-80, University Christian Movement, Johannesburg.

Buthelezi, S., 1991, 'The emergence of black consciousness', in B. Pityana \& M. Ramphele (eds.), Bounds of possibility: The legacy of Steve Biko and black consciousness, pp. 111-129, David Philip, Cape Town.

Changuion, L. \& Steenkamp, B., 2012, Disputed land: The historical development of the South African land issue, pp. 1652-2011, Protea Book House, Pretoria.

Cone, J., 1978, 'Black theology and black liberation', in M. Motlhabi (ed.), Essays on black theology, pp. 28-36, University Christian Movement, Johannesburg.

Davenport, T.R.H., 1987, South Africa: A modern history, MacMillan Press, London.

Du Toit, C.W., 2008, 'Black consciousness as an expression of radical responsibility: Biko an African Bonhoeffer', in C.W. Du Toit (ed.), The legacy of Stephen Bantu Biko: Theological challenges, pp. 209-238, Unisa Press, Pretoria.

Duncan, G., 2008, 'Steve Biko's religious consciousness and thought and its influence on theological education with special reference to Federal Theological Seminary of Southern Africa', in C.W. Du Toit (ed.), The legacy of Stephen Bantu Biko: Theological challenges, pp. 115-140, Unisa Press, Pretoria.

Khoapa, B., 2008, 'African diaspora: Intellectual influences on Steve Biko', in C.W. du Toit (ed.), The legacy of Stephen Bantu Biko: Theological challenges, pp. 73-87, University Christian Movement, Johannesburg.

Lodge, T., 1983, Black politics in South Africa since 1945, Ravan Press, Johannesburg.

Marsh, R., 2013, Understanding Africa and the events that shaped its destiny, LAPA Publishers, Pretoria.

Motlhabi, M., 1972a, 'Black theology: A personal opinion', in M. Motlhabi (ed.), Essays on black theology, pp. 53-59, University Christian Movement, Johannesburg.

Motlhabi, M., 1972b, 'Foreword', in M. Motlhabi (ed.), Essays on black theology, pp. 2, University Christian Movement, Johannesburg.

Motlhabi, M., 2008, African Theology/Black Theology in South Africa: Looking back, moving on, Unisa Press, Pretoria.

Motsoko, P., 1984, Apartheid: The story of a dispossessed people, Marriam Books, London.

Murove, M.F., 2009, 'Beyond the savage evidence ethic: A vindication of African ethics', in M.F. Murove ed.), African ethics, pp. 14-32, University of KwaZulu-Natal Press, Pietermaritzburg.

Mzimela, S.E., 1983, Apartheid: South African Naziism, Vantage Press Inc., New York.

Odendaal, A., 2012, The founders: The origins of the ANC and the struggle for democracy in South Africa, Jacana Media, Johannesburg.

Pityana, B., 2008, 'Reflections on 30 years since the death of Steve Biko: A legacy revisited', in C.W. Du Toit (ed.), The legacy of Stephen Bantu Biko, pp. 1-14, Unisa Press, Pretoria.

Pityana, N.B., 1972, 'What is black consciousness?', in M. Motlhabi (ed.), Essays on black theology, pp. 37-43, University Christian Movement, Johannesburg.

Ramphele, M., 1991, 'Empowerment and symbols of hope', in N.B. Pityana \& M. Ramphele (eds.), Bounds of possibility: The legacy of Steve Biko, pp. 154-178, David Philip, Cape Town.

Seleoane, M., 2008, 'The development of black consciousness as a cultural and political movement (1967-2007)', in C.W. Du Toit (ed.), The legacy of Stephen Bantu Biko: Theological challenges, pp. 15-56, Unisa Press, Pretoria.

Sono, T., 1993, Reflections on the origins of black consciousness in South Africa, HSRC, Pretoria.

Stubbs, A., 1978a, 'Martyr of hope', in A. Stubbs (ed.), I write what I like, pp. 154-216, The Bowerdean Press, London.

Stubbs, A., 1978b, 'Introduction', in A. Stubbs (ed.), I Write what I like, pp. 1-2, The Bowerdean Press, London.

Wilson, L., 1991, 'Bantu Stephen Biko: A life', in N.B. Pityana \& M. Ramphele (eds.), Bounds of possibility: The legacy of Steve Biko \& Black Consciousness, pp. 15-77, David Philip, Cape Town. 